\title{
Zjawiska niewłaściwych postaw w szczecińskim sporcie w latach 1945-1956
}

\author{
Abstract \\ Phenomenon of improper attitude in Szczecin sport \\ during the years $1945-1956$
}

\begin{abstract}
This paper presents historical, social and political conditions of development of sport in Szczecin Voivodship during the years 1945-1956. It draws attention to the occurrence of improper phenomenon including demoralization of this environment starting with aggressive, hooligan attitudes to the corruption symptoms. The subject of this analysis is also the policy of the authorities towards the society and its influence on forming of ethics/morality of the sports world.
\end{abstract}

\section{Wprowadzenie}

Postawy agresji leżące w naturze człowieka od najdawniejszych czasów warunkowały jego zachowanie, a w latach współczesnych często umożliwiały sukces sportowy. Wraz z popędami seksualnymi gwarantowały przetrwanie i dominację nad innymi grupami, zarówno świata zwierzęcego, jak i ludzkiego. Wrodzony instynkt był zatem wynikiem długiego procesu historycznego, walki z siłami natury, zewnętrznym i wewnętrznym przeciwnikiem (Grażewicz, Sankowski 2007, s. 502-513). Należy jednak dodać, że stan potencjalnej agresji, jej społeczna kontrola, stosunek do słabych i kalekich, poziom empatii danej społeczności świadczyły o stopniu jej rozwoju i kultury. 
Trudne warunki, w jakich znalazła się Rzeczpospolita w XVII wieku, walka z zewnętrznym zagrożeniem, utrata niepodległości, działania zaborców wobec ludności polskiej, demoralizacja społeczeństwa podczas I i II wojny światowej, jak i polityka komunistów w czasach stalinowskich, generowały liczne negatywne zjawiska w kontaktach międzyludzkich i wpływały na procesy historycznego rozwoju polskiego społeczeństwa. Szczególnie negatywnie należy ocenić lata okupacji (1939-1945). Polityka państw totalitarnych: Związku Radzieckiego i nazistowskich Niemiec skutecznie niszczyła więzi międzyludzkie. Wprowadzała podejrzliwość i rozpowszechniała terror. Działania wbrew normom społecznym i ogólnie przyjętym zasadom współżycia między narodami, uprzedmiotowienie człowieka, odwracały bieg społecznej ewolucji. Życie w strachu, nieprzewidywalność okupanta, a także trudności aprowizacyjne wzbudzały skrajne emocje: lęk, apatię, odruch patriotycznego oporu, ale również agresję i pragnienie przetrwania za wszelką cenę, nawet kosztem innych. Także bierność ludności w sytuacji prześladowań i egzekucji należy zaliczyć do zjawisk, które napiętnowały pokolenia czasu wojny. W trudnych powojennych warunkach nader często występowały postawy cynizmu, obłudy i cwaniactwa, które pozwalały na względnie dostatnie życie czy bogacenie się.

Pomorze Zachodnie, które zostało włączone w granice Polski w 1945 roku, stało się swoistym poligonem działań band nastawionych na grabież, miejscem schronienia dla prześladowanych, ale także zwyczajnych kryminalistów. Szczególnie uciążliwe były działania rabunkowe żołnierzy radzieckich, niejednokrotnie kończące się gwałtami i zabójstwami. Jedną z ofiar pijanych radzieckich żołnierzy był na przykład piłkarz Milicyjnego Klubu Sportowego, który został zastrzelony podczas nocnej służby w Szczecinie w 1946 roku. Wobec ogólnej demoralizacji społeczeństwa przetrwanie w tak trudnych warunkach, na terenach bez polskich tradycji i bez sankcji społecznych lokalnych środowisk utrwalonych wielopokoleniowym bytem, okazywało się często nie do zniesienia i powodowało nieustanną fluktuację osadników. Także polityka władz, pomimo szczytnych deklaracji, nie wychodziła naprzeciw nowym mieszkańcom. Zwykle pozostawały tam zatem grupy, dla których Pomorze Zachodnie było jedynym i ostatecznym przystankiem wędrówki, na przykład z terenów anektowanych przez Związek Radziecki czy innych ziem, zniszczonych działaniami wojennymi lub okupacyjną polityką najeźdźców.

\section{Cel pracy}

Celem niniejszej pracy jest przedstawienie różnych nieprawidłowości, które zaczęły się pojawiać w sporcie na terenie województwa szczecińskiego w latach 1945-1956. Autor starał się odpowiedzieć na pytanie, w jakim stopniu demoralizacja społeczeństwa latami okupacji, zmiany jej struktury społecznej, ale także polityka władz wpływały na kształtowanie się środowisk sportowych oraz występowanie zjawisk nieetycznych. 


\section{Materiał i metoda badań}

W procesie badawczym zastosowano metodę dedukcyjno-indukcyjną, analizę materiałów archiwalnych, prasowych, opracowań naukowych oraz literatury przedmiotu.

\section{Wyniki badań}

Przyłączenie do Polski Pomorza Zachodniego w 1945 roku jako tzw. ziem odzyskanych rozpoczęło ruch osadniczy. Pomimo zarysowanych wcześniej uwarunkowań jednymi z pierwszych działań przybywających osadników była organizacja życia sportowego. Świadczyła wymownie o utrwalonej w świadomości kulturze fizycznej, chęci powrotu do normalności, oddania się pasji, ale też ucieczki od problemów dnia codziennego. Oczywiście działalność ta była możliwa w większych skupiskach o charakterze miejskim. Tam bowiem spotkali się przedstawiciele różnych przedwojennych klubów sportowych. Można śmiało powiedzieć, że była to swoista elita środowisk wielkomiejskich, a czas po zaprzestaniu działań wojennych stał się dla nich sygnałem do energicznej pracy organizacyjnej. Z początku w samym Szczecinie w Klubie Sportowym „Odra” skupili się zawodnicy i działacze ze środowiska poznańskiego, czyli w zasadzie pracownicy różnych miejskich instancji, w Kolejowym Klubie Sportowym - gracze krakowscy i warszawscy, a w Wojskowym KS - żołnierze zza Buga i z Lubelszczyzny („Kurier Szczeciński”, nr 82, 13 IV 1946). Dość szybko jednak następowała fluktuacja i wzajemne przenikanie pomiędzy poszczególnymi regionalnymi środowiskami.

Od samego początku rozwoju stadionowej rywalizacji w kręgach samych działaczy i zawodników, ale także wśród opinii publicznej niekwestionowana była zasada fair play, popularyzowana też na łamach prasy - uczciwego postępowania w walce sportowej i grze, która miała cechować prawdziwego sportowca nie tylko na boisku, ale i w życiu codziennym. Znany w późniejszym okresie sprawozdawca radiowy Bohdan Tomaszewski w 1946 roku przedstawiał sportowców w samych superlatywach, ukazując ich trud w pionierskim rozwoju sportu i przeciwstawiając ich grupom, których celem działalności na Pomorzu Zachodnim było szybkie wzbogacenie się („Kurier Szczeciński”, nr 3, 4 I 1946). W innych miejscowościach organizacje sportowe miały charakter ogólnomiejski i aktywizowały przedstawicieli różnych środowisk zawodowych. Same imprezy sportowe przyśpieszały też wzajemną integrację. Po latach Franciszek Paszel wspominał okradanie domów i sklepów w niedzielne popołudnia w Białogardzie. Wszyscy bowiem mieszkańcy spędzali wspólnie czas na miejskim stadionie, gdzie odbywały się pojedynki piłkarskie („Tygodnik Świdwiński”, nr 3, 28 III 2002).

Spontaniczną integrację wspomagała sama władza, dla której proces polonizacji był bardzo istotnym celem politycznym. Dlatego też wszelkie ekscesy 
chuligańskie przyjmowano jako niepowodzenia działań partii PPR/PZPR, traktując je jako zjawisko szczególnie niepożądane. W 1946 roku zorganizowano w Szczecinie pierwsze Igrzyska Ziem Odzyskanych - miały one wymowę wysoce propagandową i stanowiły oficjalną manifestacją postępującej integracji tych ziem z resztą kraju.

Tak jak rosła wzajemna sympatia do sąsiadów, tak szybko pojawiała się niechęć w stosunku do obcych. Stopniowo też, wraz ze wzrostem poczucia bezpieczeństwa, rozluźniały się więzi wzajemnej solidarności. Wróciły dawna podejrzliwość i stan ciągłego zagrożenia. Na zawodach sportowych drużyny przyjezdnych stawały się obiektem kpin i pogróżek. Postawy wrogości wobec nieznajomych można by tłumaczyć charakterystycznymi zachowaniami w środowisku wiejskim. Chodzi mianowicie o nieufność wobec obcych. Przy znacznej liczbie widzów sięgającej kilku tysięcy osób w samym Szczecinie, bo sport był wówczas jedną z nielicznych rozrywek, negatywne postawy wobec pojedynczych zawodników czy całych zespołów mogły rozchodzić się w falach zachowań zbiorowych. Przy znacznej demoralizacji społeczeństwa o tego typu reakcje nie było trudno. Oczywiście frustracje widzów mogły pogłębiać między innymi brutalne zagrania piłkarzy, niekompetencja i rażące błędy sędziów. Brakowało bowiem kwalifikowanych arbitrów. W pierwszym okresie po wojnie i w mniejszych ośrodkach w ramach rozgrywek Okręgowego Związku Piłki Nożnej mecze były prowadzone przez osoby bez odpowiednich kwalifikacji, zazwyczaj przez samych działaczy czy przez osoby wybierane spośród publiczności. W takich warunkach wulgarne wyzwiska czy obelgi łatwo zyskiwały aplauz widowni. Nieżyczliwość i postawy szowinizmu spotykały także zawodników Żydowskiego Klubu Sportowego na meczach wyjazdowych („Głos Szczeciński”, nr 184, 6 VII 1948). Demoralizacja społeczeństwa, w tym przypadku widowni sportowej, wpływała także na zachowania samych zawodników. Dość ostra w swoim przebiegu rywalizacja sportowa, jaką była wówczas piłka nożna, wobec negatywnego wzmocnienia płynącego spoza boiska musiała zapewne potęgować brutalną grę samych piłkarzy. Nie bez znaczenia pozostawał społeczny mechanizm tzw. uczenia się zachowań. Kibice oczekiwali od zawodników bezkompromisowości i twardej walki, wywierając określoną presję (Grażewicz, Sankowski 2007, s. 507-509). Nawet Bohdan Tomaszewski, oceniając piłkarzy, upatrywał wad w zbyt „miękkiej” postawie na boisku („Kurier Szczeciński”, nr 98, 6 V 1946). Dlatego też mecze z reguły przypominały wtedy tak zwane polowanie na kości. Emocje często wyrywały się spod kontroli. Kiedy Jan Polewski, ceniony w późniejszym okresie szkoleniowiec, zaatakował leżącego obrońcę, który zakrywał ciałem piłkę, kopiąc go, oburzona publiczność wpadła na boisko. Od przykrych konsekwencji uchroniła go interwencja obecnych na meczu funkcjonariuszy bezpieczeństwa publicznego („Kurier Szczeciński”, nr 74, 4 IV 1946). Szczególnie brutalnie, a także nie do końca „uczciwie”, według relacji dziennikarzy, grały zespoły wojskowe. Zarówno polskich żołnierzy, jak i angielskich gości. Podczas jednego z takich spotkań dwóch graczy z zespołu KS „Odra” Szczecin trzeba było znieść z boiska ze względu na kontuzje odniesione wskutek ostrych wejść Anglików („Kurier Szczeciński”, nr 59, 13 XII 1945). Jeden z zawodników KS „Pionier” Szczecin opisywał wojskowego bramkarza, który chował 
pistolet pod leżącą przy słupku czapką i używał go jako „straszaka” na młodych przeciwników („Kurier Szczeciński”, nr 3, 9 X 1945; nr 27, 6 XI 1945; nr 59, 13 XII 1945).

Od 1946 roku na łamach prasy zaczęły się pojawiać artykuły na temat chuligańskich zajść na meczach piłkarskich. Pierwsza tego typu informacja została zamieszczona w lipcowym numerze „Kuriera Szczecińskiego” (nr 160, 17 VII 1946). Dochodziło do bójek między zawodnikami, kibicami i oczywiście między widzami a zawodnikami. W tym ostatnim przypadku zazwyczaj zdarzały się pobicia piłkarzy przez „rozwydrzoną” publiczność i obrzucanie ich kamieniami. Ofiarami niezadowolenia publiki padali także sędziowie. Zapędy najbardziej pobudliwych kibiców próbowali tonować arbitrzy, a gdy się to nie udawało - funkcjonariusze milicji. Zajścia tego rodzaju były stale piętnowane przez prasę i zarząd Okręgowego Związku Piłki Nożnej. Przede wszystkim świadczyły o fatalnej atmosferze panującej wśród polskich osadników, przecząc o szybkiej bezkolizyjnej integracji społeczeństwa na tzw. ziemiach odzyskanych, burząc przy okazji propagandę kultury fizycznej. Iskrą zapalną mogły być niewłaściwe decyzje sędziów, którzy reprezentowali zróżnicowany poziom. O pomyłki nie było też trudno, zwłaszcza że do 1948 roku pojedynki piłkarskie prowadził tylko jeden arbiter. Niemniej zawsze brano w obronę sędziów i przysługujący im margines błędu. Karano zatem kluby i zawodników zawieszeniami trwającymi od kilku tygodni do rocznych dyskwalifikacji. Zamykano boiska na określony czas, przyznawano walkowery i nakładano kary finansowe. Fundowano też specjalne nagrody dla drużyn „dżentelmenów”, które w rozgrywkach zachowywały się zgodnie z zasadą fair play. Od 1948 roku zaczęto na łamach prasy drukować imienne listy nagannie zachowujących się zawodników i działaczy wraz z wysokością nałożonych kar.

Ograniczenie napływu informacji o agresji na imprezach sportowych nastąpiło w okresie budowy kultury fizycznej opartej na wzorach radzieckich, czyli od 1949 roku. W latach 1949-1956 były to już kontrolowane relacje. Nie należało bowiem ukazywać socjalistycznego sportu w negatywnym świetle. Dopuszczano określoną krytykę jako tzw. wentyl bezpieczeństwa i w ramach poszukiwania „kozła ofiarnego”, odpowiedzialnego za niepowodzenia polityki państwa w tym obszarze życia.

Postawy agresji często widoczne były w środowisku bokserskim i wśród zgromadzonej widowni. I tak na przykład instruktor „Gwardii” Słupsk uderzył w twarz (lub spoliczkował) trenera „Skry” Szczecin Kazimierza Sworzeniowskiego podczas dyskusji nad werdyktem sędziowskim („Kurier Szczeciński”, nr 246, 6 IX 1948). Ostatecznie sprawa zakończyła się sześciomiesięczną dyskwalifikacją dla przedstawiciela klubu milicyjnego. Zawieszeni zostali także kierownik i dwóch zawodników „Gwardii”. Nie wiadomo, czy w akcie zemsty, czy też z przyczyn obiektywnych ofiara omawianego zajścia również została zawieszona na trzy miesiące z pełnienia funkcji kierownika i sekundanta za niedopatrzenia w zawodach sportowych („Kurier Szczeciński”, nr 302, 31 X 1948). Bokserzy, podobnie jak piłkarze, byli nader często karani. Równie często stosowano wobec nich „akt łaski”. Każdy zawodnik był bowiem na przysłowiową wagę złota. Karencje więc odpowiednio skracano lub nawet anulowano nałożone wcześniej kary. 
Bokserzy różnie też byli postrzegani. W Koszalinie w 1948 roku jeden z zawodników został wyrzucany ze szkoły ze względu na uprawianą dyscyplinę sportu („Kurier Szczeciński”, nr 59, 29 II 1948; nr 71, 12 III 1948). Mogło to też być wyrazem negatywnego nastawienia środowisk pedagogicznych do sportu klubowego w tym okresie.

Wybuchy niekontrolowanej złości mogły mieć różne pozasportowe podłoże. Dziś trudne niestety do identyfikacji. Weźmy przykład meczu pomiędzy miejscowym „Orłem” Wałcz a „Zrywem” Szczecinek w rozgrywkach B klasy. Podyktowanie karnego dla gości wywołało niezadowolenie widowni i zarówno sędzia, jak i sami piłkarze „Zrywu” musieli opuścić boisko pod eskortą milicji. W innym nieco świetle ocenimy to zajście, jeśli uświadomimy sobie, że w Wałczu zamieszkała liczna grupa osadników z Kresów, m.in. z Korca, miasta granicznego przed drugą wojną światową ze Związkiem Radzieckim. Ich stosunek do władzy ludowej będącej na usługach Rosjan był zapewne mocno negatywny. Decyzja sędziego dająca szansę odrobienia strat w końcówce meczu zawodnikom klubu działającego przy Związku Walki Młodych, utożsamianym z komunistami, musiała wywołać oburzenie publiczności. I tak naprawdę w tym momencie nie miało żadnego znaczenia, czy była to decyzja słuszna, czy też nie („Głos Szczeciński”, nr 130, 26 X 1947). Podobny charakter miało zajście na boisku w Szczecinku w 1949 roku. Na meczu pomiędzy „Darzborem” Szczecinek a „Gwardią” Słupsk doszło do awantury pomiędzy publicznością a funkcjonariuszami MO ze Słupska, którzy przyjechali na pojedynek piłkarski jako kibice. Wówczas to miejscowi cywile pobili jednego z elewów Centrum Wyszkolenia MO ze Słupska. Należy jednak zaznaczyć, że to właśnie milicjanci zachowywali się agresywnie i byli ponadto pod wpływem alkoholu (Akta w sprawie zajścia na boisku sportowym w Szczecinku, 1949, IPN, Oddział w Szczecinie, sygn. IPN Sz 397/3969, k. 6).

Analizując sytuację w sporcie na Pomorzu Zachodnim w 1950 roku, ubolewano nad chuligańskim zachowaniem kibiców, dopatrując się jego przyczyn w braku oddziaływań wychowawczych, w tym także o charakterze politycznym, aktywu klubowego wśród lokalnej społeczności. Wymieniano: awantury, wrzaski, rzucanie przedmiotami i łamanie ławek. Po jednym z meczów bokserskich w Szczecinie niezadowolona publiczność powybijała szyby w hali sportowej (Protokoły zebrania Sekcji Sportowej KW PZPR, 1950, APSz, KWPZPR w Szczecinie, sygn. 3467, k. 15). Obrzucanie sędziów wyzwiskami, niezależnie od ich postawy, stawało się codziennością.

Do negatywnych zachowań należało też korzystanie z nieuprawnionych do gry zawodników i inne oszustwa. W zawodach uczestniczyli niejednokrotnie niezgłoszeni do rozgrywek piłkarze lub będący członkami innych kół czy klubów. Częstym zjawiskiem było też podwójne podpisywanie kart zgłoszeń. W przypadku zawodników zgłoszonych w okręgowych związkach innych województw wykrycie takiego faktu było utrudnione. Fałszowano badania lekarskie, które były wymagane na zawodach sportowych oraz grano na dokumentach innych zawodników. Powszechne były też fałszerstwa w oficjalnych sprawozdaniach. Dotyczyły organizacji imprez, szkoleń ideologicznych, liczby członków czy uzyskanych norm odznaki Sprawny do Pracy i Obrony. 
Dużym problemem wśród sportowców, ale także w całym społeczeństwie, było nadużywanie alkoholu. Jeden z przypadków, który najlepiej przedstawiał podobne zwyczaje, odnotował szczeciński dziennikarz, kiedy na „Pierwszym kroku bokserskim" młodego zawodnika, po zwycięsko stoczonej walce, jeden z działaczy poczęstował wódką („Kurier Szczeciński”, nr 325, 24 XI 1948). Zdarzały się też wypadki zawieszania zawodników na określony czas za pijaństwo lub za niesportowe zachowanie w stanie nietrzeźwym na zawodach sportowych („Kurier Szczeciński”, nr 330, 29 XI 1948; nr 340, 9 XII 1948). Dyskwalifikacje zdarzały się także za kilkukrotne niestawienie się na zawody sportowe bez usprawiedliwienia. Tu możemy się tylko domyślać, jakie były faktyczne powody absencji.

Problem alkoholizmu i złodziejstwa dotykał szczególnie środowisko wiejskie pozbawione często szerszych perspektyw życiowych. Działacze sportowi często sygnalizowali pijaństwo młodzieży, która przychodziła na boisko w stanie nietrzeźwym, zachowując się wulgarnie. W gminie Trzebieszewo (powiat kamieński) na boisku miejscowego LZS młodzież grała, zakładając się o ćwiartkę wódki. Inna grupa, ze spółdzielni produkcyjnej i PGR, spędzała czas w knajpie i na wałęsaniu się po ulicy (Protokoły z posiedzeń Prezydium Zarządu Powiatowego ZMP w Kamieniu Pomorskim, 1953, APSz, KW PZPR w Szczecinie, sygn. 2225, k. 2). Zaczęto jednak dostrzegać i wychowawczą rolę sportu.

Kiedy odbywał się kurs przodowników wychowania fizycznego w Wojewódzkim Ośrodku Kultury Fizycznej w Szczecinie, zorganizowany dla członków i aktywistów ZMP (7-26 XI 1949 r.), zmagano się z brakiem karności, tzw. bałaganiarstwem i wulgarnym zachowaniem młodzieży (Protokoły posiedzeń Organizacji Partyjnej i Rady Związków Zawodowych przy WKKF, 1949-1950, APSz, PWRN w Szczecinie, sygn. 11363, k. 1). Sprawozdania Sekcji Piłki Nożnej PKKF na terenie województwa szczecińskiego w latach 1953-1956 pełne są informacji na temat pijaństwa i chuligaństwa piłkarzy, a także oszustw z podpisywaniem nawet kilku kart zgłoszeń. Opisywano też wybryki chuligańskie kibiców.

Szczególnie naganne było kaperownictwo, które utożsamiano z wypaczeniami sportu wyczynowego w krajach kapitalistycznych i tzw. sportu burżuazyjnego w przedwojennej Polsce. Pogoń za wynikami powodowała próby nakłaniania zawodników do zmian barw klubowych za odpowiednią finansową bonifikatą lub za inne korzyści. Jako że sport w Polsce Ludowej nabierał ideowych wartości, a sportowcy reprezentowali świat pracy, tego typu działania odbierane były wręcz jako wroga działalność wobec klasy robotniczej i idei socjalistycznego sportu. Oczywiście z chwilą wprowadzenia wzorca radzieckiego przechodzenie z klubu do klubu było ograniczone. Wiązało się to bowiem z koniecznością zmiany zatrudnienia lub, na przykład, poborem do wojska (kluby wojskowe) czy przejściem na służbę do milicji (kluby gwardyjskie). Wszystkie przypadki, jeśli było to możliwe, starano się piętnować. Oczywiście nie jest przypadkiem, że najwięcej szumu robiły rywalizujące organizacje, które najwięcej traciły przy wzmacnianiu się konkurentów w rozgrywkach. Nawet jeden z najlepszych szczecińskich bokserów został ukarany surową naganą przez OZB za usiłowanie kaperowania zawodników („Kurier Szczeciński”, nr 287, 16 X 1948). Rzecz jasna żadne zakazy wcale nie powodowały zaniechania podobnych praktyk przez działaczy sportowych. 
W tym miejscu należy zaznaczyć, że ziemie przyłączone do Polski traktowane były przez władze sportowe odmiennie zaraz po wojnie. Na nadzwyczajnym zebraniu Polskiego Związku Piłki Nożnej w dniach 14-15 XII 1946 roku podjęto decyzję, że zawodników przyjeżdżających na „Ziemie Odzyskane” i zasilających miejscowe kluby nie będzie obowiązywała regulaminowa karencja, czyli przerwa w rozgrywkach ligowych (Protokół zebrania OZPN odbytego w dniu 10 XII 1956, APSz, PWRN w Szczecinie, sygn. 11489, k. 71). Także w późniejszych latach działacze szczecińscy usprawiedliwiali własne działania i tzw. kaperownictwo utrudnionym startem organizacyjnym i szkoleniowym po drugiej wojnie światowej.

Ze względu na zmiany generacyjne i cywilizacyjne trudno porównywać zachowania korupcyjne $z$ lat 70 . i 80 . XX wieku w polskim sporcie do wypaczeń z lat 40. i 50. Można raczej mówić o różnych formach nacisku, zwłaszcza że w rozgrywkach brały udział zespoły milicjantów czy wojskowych, a sami działacze pełnili różne funkcje społeczne i zawodowe. Byli często zarówno sędziami sportowymi, jak i działaczami klubów, zrzeszeń oraz związków sportowych. Kiedy na przykład Kolejowy Klub Sportowy rozegrał zwycięski mecz z Pocztowym KS, dziennikarz „Kuriera Szczecińskiego” Bohdan Tomaszewski zarzucił sędziemu Marianowi Wochance stronniczość („Kurier Szczeciński”, nr 100, 8 V 1946). Szczeciński arbiter był wówczas działaczem kolejowego klubu, co mogło po prostu wpływać na jego decyzje. Warto jednak dodać, że M. Wochanka był jednym z nielicznych kwalifikowanych sędziów piłkarskich w tym czasie i cieszył się ogólnym poważaniem za reprezentowany poziom podczas sędziowania zawodów sportowych. Nie ma relacji, które potwierdzałyby akty przekupstwa, świadomość społeczna występowania tego typu zachowań była jednak powszechna i na meczach, które kończyły się niekorzystnym wynikiem dla gospodarzy, komentarze o sprzedajności piłkarzy i ustawionych wynikach były częstym zjawiskiem („Kurier Szczeciński”, nr 254, 13 IX 1948). Na zebraniu sportowego aktywu partyjnego KW PZPR w 1949 roku działacz „Gwardii” Myślibórz krytykował „system kaperowania oraz przekupstwo graczy i ich rozpijanie" (Uchwały i wytyczne Egzekutywy KW PZPR w sprawie sportu, APSz, KW PZPR, sygn. 3466, k. 20). Deklaracje walki z przekupstwem i kaperowaniem zawodników zostały wpisane do sprawozdania z działalności ZS Związkowiec w Szczecinie z 10 listopada 1949 roku (Uchwały i wytyczne Egzekutywy KW PZPR w sprawie sportu, APSz, KW PZPR, sygn. 3466, k. 102). Inny szczeciński piłkarz Milicyjnego Klubu Sportowego, późniejszej „Gwardii”, stwierdził, że w latach pięćdziesiątych chodziły słuchy o ustawianiu meczów, ale nie w Szczecinie. Oczywiście szczeciński sport nie dysponował wówczas jeszcze odpowiednio wysokimi funduszami i tzw. lewą, czy inaczej - czarną kasą, potrzebną na nieoficjalne transakcje. Zresztą podobne zachowania, w przypadku wykrycia i oczywiście nagłośnienia, byłyby wówczas bardzo surowo karane. To wszystko nie oznacza, że nie było przypadków przekupstwa czy po prostu kumoterstwa. W tym miejscu należy dodać, że i trenerzy czołowych polskich zespołów w latach 80. XX wieku, potwierdzając proceder handlowania punktami, z pełną powagą deklarowali uczciwość własnych środowisk.

Duży wpływ na kształtowanie się środowisk sportowych i całego społeczeństwa miała polityka państwa wobec obywateli. Zgodnie z zasadami propagandy, podporządkowania i ubezwłasnowolnienia społeczeństwa stosowano cały arsenał 
środków. Szukano na przykład wroga klasowego, mobilizując poszczególne środowiska do określonych działań, strasząc, ale też szukając kozła ofiarnego odpowiedzialnego za niedomagania systemu. Ten mechanizm stosowany był także na tzw. odcinku sportu. Ofiarą takiej polityki padł na przykład Chałaśny jako „skompromitowany z okresu okupacji”. Krytykowano też działalność klubów sportowych w latach 1945-1948 jako spadkobierców i kontynuatorów niechlubnych „burżuazyjnych form i metod”, które koncentrowały się na sporcie wyczynowym, odciągając młodzież od „walki klasowej” i od walki o realizację planów gospodarczych itp. Nagonka objęła też Minnickiego, kierownika Okręgowej Rady Kultury Fizycznej i Sportu Okręgowej Rady Związków Zawodowych (Uchwały i wytyczne Egzekutywy KW PZPR w sprawie sportu, APSz, KWPZPR, sygn. 3466, s. 37).

Pod koniec 1949 roku, czyli po Uchwale Biura Politycznego Komitetu Centralnego PZPR „W sprawie kultury fizycznej” z dnia 28 września 1949 roku, powstała przy KW PZPR w Szczecinie Sekcja Sportowa. Niniejsza uchwała wzorowana była na uchwale Komitetu Centralnego Wszechzwiązkowej Komunistycznej Partii (bolszewików) z 27 XII 1948 roku (Szymański 2004, s. 45). Jej zadaniem w pierwszym okresie obowiązywania było przede wszystkim zadbanie o oczyszczenie kadr działaczy w zarządach okręgowych związków sportowych z „elementu reakcyjnego i klasowo obcego" (Protokoły posiedzeń Prezydium WKKF, 1950-1951, APSz, PWRN w Szczecinie, sygn. 11319, k. 75). Postulowano wejście aktywistów ZMP, związków zawodowych do zarządów klubów, kół LZS i związków sportowych w myśl hasła „walki o czyste i zdrowe kadry sportowe”.

Józef Szlejfer, członek Zarządu Okręgowego Kolegium Sędziów OZPN, na walnym zebraniu w dniu 1 kwietnia 1950 roku wzywał do wyeliminowania „obcych klasowo" sędziów z grona kolegium. Inny arbiter zarzucał ustępującemu zarządowi zbyt małą liczbę referatów ideologicznych. Z listy sędziów zostali skreśleni Kowalski, który był jednocześnie sekretarzem Okręgowego Kolegium Sędziów, i Szmid (Protokoły posiedzeń Zarządu Okręgowego Kolegium Sędziów, 1950-1951, APSz, PWRN w Szczecinie, sygn. 11634, k. 1-3).

Proces indoktrynacji dosięgnął oczywiście i młodzieży. Takie działania były szczególnie ważne na wsi w procesie jej kolektywizacji. Wobec braku kół ZMP podobną rolę odgrywały koła LZS, w których nastawiano młodzież przeciw rodzicom i włączano ją w działania brygad szukających schowanego przez rolników zboża. Kształtowanie podobnych postaw generowało szereg negatywnych zjawisk społecznych, nie sprzyjając procesom wychowawczym. Boiska LZS były też często miejscem zachowań chuligańskich. Nawet podczas propagandowych meczów w ramach akcji łączności miasta ze wsią dochodziło do różnych ekscesów.

\section{Podsumowanie}

Pomimo obiektywnie nieocenionych walorów sportu należy podkreślać negatywne skutki jego wynaturzeń. W omawianym okresie wielu młodych ludzi rozpoczynało uprawianie sportu dopiero po drugiej wojnie światowej. Zjawiska 
demoralizacji, z którymi się stykali, negatywnie kształtowały ich własne postawy. Dotyczyło to szczególnie piłki nożnej i związanej z nią agresji boiskowej. W wielu innych przypadkach: gimnastyki, kajakarstwa, lekkiej atletyki, kolarstwa itp., wobec odmiennego charakteru rywalizacji i przy braku określonych nacisków, w tym i kibiców, nie dochodziło do nagromadzenia w takim stopniu negatywnych zjawisk.

Polityka władz oraz ideologizacja kultury fizycznej, rozdźwięk pomiędzy propagandą a rzeczywistością, usportowienie na siłę, generowały szereg negatywnych zjawisk społecznych i przyczyniały się do upadku przeświadczenia o wychowawczej roli kultury fizycznej, w tym szczególnie sportu. Z wieloma skutkami polityki władz w latach PRL-u przychodzi nam zmagać się do dziś.

\section{Literatura}

\section{Materiały archiwalne}

Akta w sprawie zajścia na boisku sportowym w Szczecinku, 1949, IPN, Oddział w Szczecinie, sygn. IPN Sz 397/3969.

Protokoły zebrania Sekcji Sportowej KW PZPR, 1950, APSz, KWPZPR w Szczecinie, sygn. 3467.

Protokoły posiedzeń Organizacji Partyjnej i Rady Związków Zawodowych przy WKKF, 1949-1950, APSz, PWRN w Szczecinie, sygn. 11363.

Protokoły posiedzeń Prezydium WKKF, 1950-1951, APSz, PWRN w Szczecinie, sygn. 11319.

Protokoły posiedzeń Zarządu Okręgowego Kolegium Sędziów, 1950-1951, APSz, PWRN w Szczecinie, sygn. 11634.

Protokół zebrania OZPN odbytego w dniu 10 XII 1956, APSz, PWRN w Szczecinie, sygn. 11489.

Protokoły z posiedzeń Prezydium Zarządu Powiatowego ZMP w Kamieniu Pomorskim, 1953, APSz, KW PZPR w Szczecinie, sygn. 2225.

Uchwały i wytyczne Egzekutywy KW PZPR w sprawie sportu, APSz, KW PZPR, sygn. 3466.

\section{Materiały drukowane}

Grażewicz J., Sankowski T., Psychologia aktywności sportowej, AWF Poznań, Poznań 2007, s. 502-513. Szymański L., Kultura fizyczna i turystyka w polityce Polski Ludowej 1944-1989, AWF Wrocław, Wrocław 2004, s. 45.

\section{Prasa}

„Głos Szczeciński” 1947-1956.

„Kurier Szczeciński” 1945-1956.

„Tygodnik Świdwiński” 2002. 